\title{
HISTORY OF FACTUMS
}

\author{
J.E. CÔTÉ*
}

The history of the factum in Canada is little known but greatly significant in the development of written argument. Written argument grew alongside the oral legal tradition. The factum developed in Canada in an unorthodox way. Unlike most Canadian laws and procedures, which find their roots in common law England, the factum originated in Quebec's civil jurisdiction before being adopted in the Northwest Territories. This article explores the evolution of written argument and the historical use of the factum in the United Kingdom and Canada and details the practice of factum use in Alberta particularly.
Bien que l'histoire du mémoire au Canada soit peu connue, elle a contribué de façon importante à l'avènement de l'argumentation écrite, qui évolué en parallèle avec la tradition de l'exposé oral. Le mémoire s'est implanté au Canada selon une voie peu orthodoxe. Contrairement à la plupart des lois et procédures canadiennes qui prennent leur fondement dans la common law de l'Angleterre, le mémoire a pris son origine dans le système de droit civil du Québec avant d'être adopté dans les Territoires du NordOuest. Outre un survol de l'évolution de l'argumentation écrite et de la façon dont on a eu recours au mémoire au Royaume-Uni et au Canada par le passé, l'article expose en détail l'utilisation du mémoire en Alberta.

\section{TABLE OF CONTENTS}

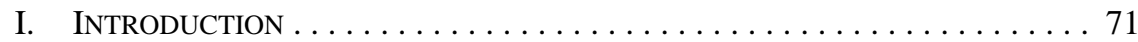

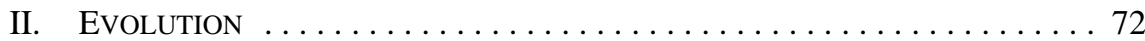

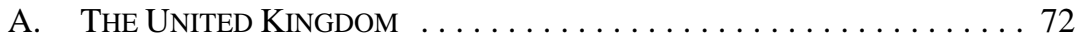

B. QUEBEC ............................... 74

C. The Supreme Court of CANAdA $\ldots \ldots \ldots \ldots \ldots \ldots \ldots \ldots \ldots$

D. THE NorthWEST TERritories $\ldots \ldots \ldots \ldots \ldots \ldots \ldots \ldots \ldots \ldots$

E. Other PRovinces: MANitoba AND ONTARIO $\ldots \ldots \ldots \ldots \ldots \ldots 78$

III. ACtual Alberta Practice $\ldots \ldots \ldots \ldots \ldots \ldots \ldots \ldots \ldots \ldots \ldots \ldots$

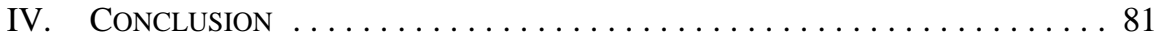

\section{INTRODUCTION}

Parties must usually give written argument to an appeal court. In Canada, such a document is called a factum. Increasing reliance upon such argument has gradually reshaped how courts work, decide, and make law. For one thing, many courts impose time limits on oral argument. Time limits emphasize that the factum is the important thing, not later oratory before the panel. Courts often offer to decide appeals on the factums alone (though there may not be many takers). But it is doubtful that oral argument commonly changes the panel's minds as to who wins. There are also practical reasons why all-written appeals are occasionally preferable, such as in an interlocutory appeal holding up a trial, or in appeals with out-of-town parties or counsel. ${ }^{1}$ So the topic is extremely important, yet the history of factums is little known. ${ }^{2}$

The Honourable Justice JE Côté is a judge on the Alberta Court of Appeal in Edmonton.

JE Côté, Well-Run Appeals (Ottawa: Canadian Judicial Council, 2006) at 104-105.

Researching this topic proved to be more challenging than one would expect. The hard research was done by Debra MacGregor. Julie Olson and Sean Kelly found rare books. When I got stuck with one point, the Legal Archives Society helped by giving me advice and archival access. The Alberta Provincial Archives gave access to all the old Alberta Appeal Court files, including factums. Erin Nelson kindly reviewed a late draft and made helpful suggestions. 
This subject is interesting from the point of view of legal history and as an aspect of procedure. Written argument grew alongside the oral legal tradition. The factum developed specifically in Canada, and in an unusual way. If one wants to know the history of some law or procedure in Alberta, it is usually safe to assume the following common pattern: the practice developed in England, then was copied by Upper Canada (Ontario), and then adopted by the Northwest Territories or the four western Canadian provinces. But the factum's history is strikingly different. This common pattern is not how factums came to the Court of Appeal in Alberta. The United States is another occasional source of outside inspiration for Canadian legal practice. But it does not appear that it had much of an early role in introducing factums to Canada either. ${ }^{3}$

The term "factum" is French for "pamphlet." 4 The word is not used for this legal topic outside Canada. Americans call such written arguments "briefs.” The English came to them in very recent years and call them "skeleton arguments" or even "skeletons.” In the sense of a written legal argument, the word "factum" seems to come from France. ${ }^{5}$

\section{EVOLUTION}

\section{A. The UnITED KINGDOM}

The word "factum" is known in Scotland, but possibly not in this precise context. In Scottish appeals to the House of Lords, the printed "case" of each party used to contain not only facts, but also argument (unlike English appeals). ${ }^{6}$ A Canadian would call that Scottish case a "factum." A Canadian would also think of appeals to the Judicial Committee of the Privy Council.

Legislation alone does not make clear what was the practice of the Judicial Committee of the Privy Council with respect to written argument. For example, its Rules called for a printed case. ${ }^{7}$ All that they said about its contents was that it should include "circumstances out of which the Appeal arises, the contentions to be urged by the party lodging the same, and the reasons of appeal."

Though the Supreme Court of the United States started using written "briefs" early in its history, it is doubtful that had much influence in Canada. See Edward Robert Cameron, Supreme Court Act R.S. c. 139 (1906) Practice and Rules: With References to All the Decisions of the Court Dealing With Its Practice and Jurisprudence, 2d ed (Toronto: Arthur Poole, 1913) at 532 [Cameron, Supreme Court Act] citing two United States Supreme Court decisions requiring a written "statement of the points and facts": Faw v Marsteller, 6 US (2 Cranch) 10 (1804); Reily v Lamar, 6 US (2 Cranch) 344 (1805). Josette Rey-Debove, ed, Le Robert Méthodique: Dictionnaire méthodique du français actuel (Paris: Le Robert, 1989) sub verbo "factum."

See Edward Weller, An Improved Dictionary: English and French and French and English (London, UK: Trübner, 1863) sub verbo "factum"; Walter A Shumaker \& George Foster Longsdorf, The Cyclopedic Dictionary of Law (St Paul: Keefe-Davidson Law Book, 1901) sub verbo "factum." Rt Hon Lord Macmillan, A Man of Law's Tale: The Reminiscences of the Rt. Hon. Lord Macmillan (London, UK: Macmillan, 1953) at 126.

Judicial Committee Rules, 1957, SI 1957/2224, rr 60-63. 
However, the commentary in Bentwich's Privy Council Practice clears the matter up. ${ }^{9}$ Of course, the printed case had to contain the relevant parts of the proceedings below, the orders below, a brief statement of the reasons or grounds of appeal, and the facts as proved below. ${ }^{10}$ But there was more: "He may also, if he please, argue the law which arises upon them, and may cite legal authority in support of the argument in such mode as he deem most expedient for the interest of his cause." ${ }^{11}$ The opposing counsel is not consulted in this.

The Rules reproduced there appear to be from the 1908 Judicial Committee Rules, but the 1925 Rules concerning the content of the printed case have the same wording. ${ }^{12}$ Cameron says that in Canadian appeals, the Supreme Court of Canada factums were reproduced in the case for the Privy Council. ${ }^{13}$ Cameron also notes that " $[\mathrm{t}]$ he term 'case' as used in England corresponds with the term 'factum' in the Supreme Court."14

The average length of Privy Council cases was eight pages. ${ }^{15}$ Cameron quotes an early twentieth century letter by Sir Edward Hope, Registrar of the Privy Council, who states that Supreme Court of Canada factums were much longer than Privy Council cases:

[T] he object of the Privy Council "cases" is not to present a complete argument of the case on one side or the other (which is reserved for the hearing), but merely to present, for ... convenience ..., a short statement of the facts ..., to emphasize or refer to ... the salient parts of the evidence or judgments, and to direct attention to the legal points at issue. ${ }^{16}$

Cameron reprints a sample Canadian case before the Judicial Committee of the Privy Council; its argument portion seems very brief. ${ }^{17}$

Those Scottish and Privy Council printed “cases” including argument may have had some influence in parts of Canada. But the unfamiliar word "factum" suggests that it may not have been direct or total influence. The word is a civil law term, ${ }^{18}$ which gives a clue: we should look at the nearest source of civil law.

Norman Bentwich, The Practice of the Privy Council in Judicial Matters (London, UK: Sweet and Maxwell, 1912) [Bentwich, Privy Council Practice].

Ibid at 286.

Ibid. Identical words are also found in Frank Safford \& George Wheeler, The Practice of the Privy Council in Judicial Matters (London, UK: Sweet and Maxwell, 1901) at 819. See also Edward Robert Cameron, The Supreme Court of Canada: Practice and Rules, supp to 3d ed (Toronto: Carswell, 1931) (having virtually identical words to Sir Edward Hope's letter at 168) [Cameron, SCC Practice and Rules].

Cameron, SCC Practice and Rules, ibid at 185.

Ibid at 164 .

Ibid at 167. See also Cameron, Supreme Court Act, supra note 3 at 526.

Cameron, SCC Practice and Rules, ibid at 168.

Ibid.

Ibid at 206-208.

See supra note 5. 


\section{B. QUEBEC}

Quebec Rules of Court on appellate practice going back as far as 1809 have been found and consulted. ${ }^{19}$ The 1809 Rules were dated and enacted by the judges on 19 January and are titled Rules and Orders of Practice in the Provincial Court of Appeals. ${ }^{20}$ The 1809 Rules provide for filing of grounds of appeal and answers thereto, early in the appeal. ${ }^{21}$ But those were doubtless mere lists of grounds. A "case" had to be filed by each party in sextuplicate, ${ }^{22}$ but no details are given. Whether it was to contain argument is not stated.

The second edition of the same book contains largely the same wording as the1809 Rules, including rule XXI. ${ }^{23}$ It still did not describe the contents of the "case." The Rules and Orders of Practice for the Court of King's Bench, District of Montreal were published in 1823 and contain substantially the same rules as well. ${ }^{24}$ New Lower Canada Rules of July Term, 1850 were published and rule 14 was very similar to the old rule XXI on the "case." 25

A Code of Civil Procedure came into force in Lower Canada a few days before Confederation. ${ }^{26}$ Article 1140 required filing “a printed factum, or case,” but did not appear to describe the contents or format of a factum, which was doubtless left to the Rules of Court. $^{27}$

Additional (unnumbered) Supplementary Rules of Practice were passed in Quebec between 1857 and 1867. Those of 11 July 1857 and 6 December 1859 both called for a "printed factum, in the same manner" for circuit court appeals as called for in the case of appeals from the Superior Court, but with heavy paper or parchment covers. ${ }^{28}$ The 1859 Rule also called for printing the evidence adduced at trial by the party filing the factum. ${ }^{29}$ The 1861 Rule also called for a copy of the judgment appealed from. ${ }^{30}$

The 16 March 1877 Quebec Court of Appeal rules allowed a special joint case instead of factums, which was to include the parties' respective arguments. ${ }^{31}$ Factums or cases were to be printed on paper eight and a half by 11 inches in "small pica, leaded" typeface, with every

Quebec, Rules and Orders of Practice in the Provincial Court of Appeals (1809), 49 Geo 3 [1809 Rules]. These cannot have been the first appellate rules because rule XXXVII repeals the former rules of practice.

Ibid.

Ibid at rr XVI-XIX.

Ibid at $\mathrm{r}$ XXI.

Quebec, Rules and Orders of Practice in the Provincial Court of Appeals, 2d ed (1818), r XXI.

Montreal, Rules and Orders of Practice for the Court of King's Bench, District of Montreal, February Term 1811 (1823), r XXI.

Quebec, General Rules of the Court in the exercise of its Civil Appellate Jurisdiction, Rules of July Term, 1850 (1850) r 14.

Ivan Wotherspoon, A Manual of the Practice and Procedure in the Several Courts Having Civil Jurisdiction in the Province of Quebec (Montreal: Dawson Brothers, 1870) at xxx-xxxiv citing Code of Civil Procedure of Lower Canada, 1866 (UK), 29 \& 30 Vict, c 25.

Ibid at 174 [emphasis in original].

Ibid, Addenda at i-ii.

Ibid, Addenda at ii.

Ibid.

Ivan Wotherspoon, A Manual of the Practice and Procedure in the Several Courts Having Civil Jurisdiction in the Province of Quebec, revised ed (Montreal: Dawson Brothers, 1880) at 269 [Wotherspoon, Revised Manual]. 
tenth line numbered in the margin. ${ }^{32}$ The factum was more important than oral argument. ${ }^{33}$ The 21 June 1879 Quebec Rules were similar to and replaced the 1857 to 1867 Rules. ${ }^{34}$ The "case in appeal" was to contain, among other things, "a summary statement of the pleadings and of the questions of fact and of law on which the party filing it relies." ${ }^{35}$ The case or factum had to be filed 48 hours before the hearing. ${ }^{36}$

Then an entirely new Code of Civil Procedure was enacted in 1897; its article 1223 required each party to an appeal to file a "printed factum or case." 37

Rule VIII of the Quebec Court of King’s Bench enacted 6 December 1917 specified that the case was to contain "propositions set forth as succinctly as possible, with references to the authorities and to the pages of the evidence upon which such propositions are supported."38

All the above demonstrates that the Quebec appellate court's practice is the ultimate ancestor of factums in Canada.

\section{The Supreme Court of CANAdA}

The Supreme Court of Canada was clearly the immediate inspiration for the Northwest Territories. The first Rules of the Supreme Court of Canada were dated February 7, 1876, and signed by Robert Cassels, the Court's Registrar. ${ }^{39}$ They were passed by the judges of the Court, pursuant to section 79 of The Supreme and Exchequer Courts Act. ${ }^{40}$

Supreme Court Rules 23-30 required that each party file a "factum or points for argument in appeal." ${ }^{41}$ Rule 24 explained that the document "shall contain a concise statement of the facts, and of the points of law intended to be relied on, and of the arguments and authorities to be urged and cited at the hearing, arranged under the appropriate heads." 42 Rule 25 required that the factum "be printed in the same form and manner" as the appeal book. ${ }^{43}$ Rule 29 provided that neither party could see the opposing factum until he had filed his own. ${ }^{44}$ That practice was followed in Alberta ${ }^{45}$ until $1974 .^{46}$

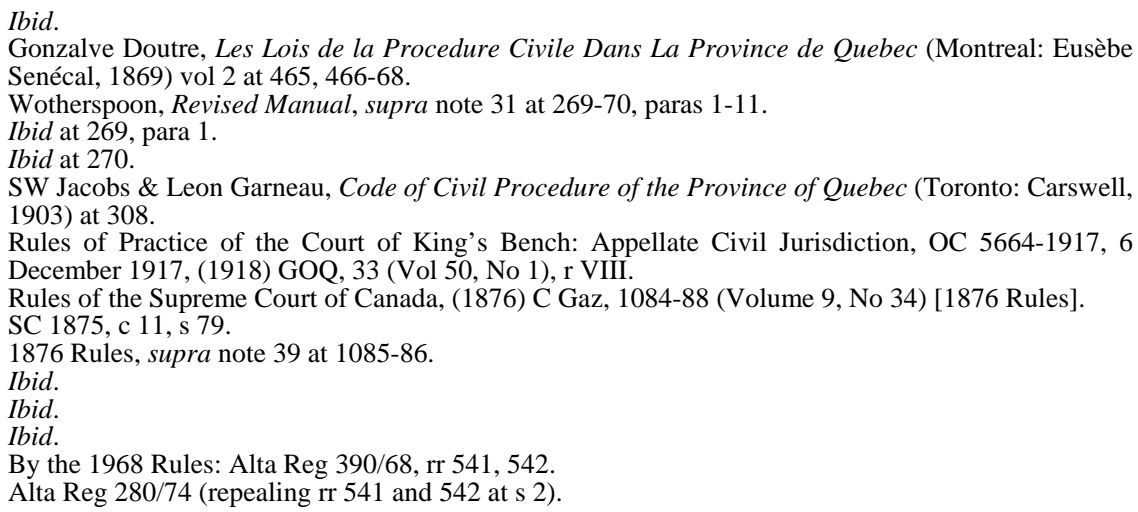


Though the wording of the Supreme Court of Canada Rules on factums is not very similar to that in the various Quebec Rules or Codes of Civil Procedure, the concept and substance are identical.

Up through 1900, only minor changes (irrelevant here) were made to the Supreme Court of Canada Rules. That is confirmed by consulting the standard work on Supreme Court of Canada practice from $1899 .{ }^{47}$ The Rules there reprinted are the identical 1876 Rules, except for a small amendment in the deadline for filing factums.

The commentary in Cassels says that counsel were also allowed to hand in after oral argument a printed list of additional authorities cited at the hearing, but not already mentioned in the factum. ${ }^{48}$ However, rarely if ever will the Supreme Court of Canada receive an "additional argumentative factum." ${ }^{49}$ Cassels also states that factums were not required in criminal appeals. ${ }^{50}$

By 1913, the Supreme Court of Canada Rules on factums had been amended to describe their contents in more detail. Rule 30 called for three parts: concise statement of facts, alleged errors of the court below, and a brief of the argument with citations. ${ }^{51}$ Cameron's book says that the newer 1913 Supreme Court of Canada Rule on the three parts of the factum was "largely modelled upon the corresponding provisions of the Supreme Court of the United States," and that the first edition of the book had given as a precedent a Supreme Court of the United States "factum." 52 The Cameron book says that it prints as a precedent a good Supreme Court of Canada factum. ${ }^{53}$

In 1931, Rule 30 was still the same. ${ }^{54}$

\section{THE NORTHWEST TERRITORIES}

The next step in tracing the idea of factums to Alberta is to examine the practice on appeals in the former Northwest Territories - Alberta and Saskatchewan got their own courts only in 1907. Appeals were heard by the Supreme Court of the Northwest Territories sitting en banc. Were there factums then?

One would naturally turn to the Northwest Territories Rules of Court which are found at the end of its Judicature Ordinance, but they are not very informative on this point. ${ }^{55}$ Rule 503 describes the notice of appeal and rule 511 describes how to put the evidence before the full court, but there is no mention of whether written argument is allowed, forbidden, or compulsory. ${ }^{56}$

Robert Cassels, The Practice of the Supreme Court of Canada, 2d ed by CH Masters (Toronto: Carswell, $1899)$ at $142-43$.

Ibid at $143-44$.

Ibid at 144 .

Ibid at 145.

Cameron, Supreme Court Act, supra note 3 at 525-26.

Ibid at 526, 531.

Ibid at 526-27 and see sample factums at 646, 654 .

Cameron, SCC Practice and Rules, supra note 11 at 114.

Rules of Court, The Judicature Ordinance, SNWT 1898, с 21 [Judicature Ordinance, 1898].

Ibid, rr 503, 511. 
However, section 437 in The Judicature Ordinance 1886 did provide that "[a]pplications to the court in banc shall be by way of re-hearing, and shall be brought by notice of motion, in a summary way, and no petition, case, or other formal proceeding, other than such notice of motion, shall be necessary." 57 That indicated plainly that as late as the late 1880s, no factum or other written argument was then needed. By 1893, the Judicature Ordinance had at the end a rule almost identical in wording to the old 414 rule. ${ }^{58}$

Within a few years came big changes. The phrase "by notice of motion" was changed to "by notice of appeal." "59 More seriously, the sentence quoted above from the old 414 rule disappeared under Ordinance No. 6 of 1897, which substituted a new Rule $505 .{ }^{60}$ That presented a small mystery. Were there to be factums? The Judicature Ordinance and its appended Rules said nothing about factums, neither for nor against. Their only express words on the topic had been deleted.

The answer is that those appended Rules were not the only Northwest Territories Rules of Court. There was a second supplemental set, entitled Consolidated Rules of the Supreme Court of the North-West Territories. ${ }^{61}$ These Rules are stated to have been passed by the judges and bear the date 20 July 1900. These 1900 Rules are not a general set of rules, and only cover a handful of distinct topics, one of which is appeals.

Rules 9 to 18 deal with "factums" in some detail, using that term. Rule 9 expressly requires from each party "a factum or statement of his points of argument before the Court." 62 Rule 10 elaborates and says that a factum is to

contain a concise statement of the facts and of the points of law intended to be relied on and of the arguments and authorities to be urged and cited at the hearing, arranged under appropriate heads. ${ }^{63}$

Rule 11 sets the format and allows printing or typewriting. ${ }^{64}$ Rules 12 and 14 call for exchange of factums between parties once both parties had them submitted to the registrar. ${ }^{65}$ Rule 16 allows factums to be dispensed with. ${ }^{66}$ Then Rule 18 returns to the topic of a factum's contents; it is to "contain in brief all the facts, points of arguments and authorities to be relied upon." ${ }^{67}$ But the Court could (on terms) allow other topics (presumably orally) which were not in the factum.

Rule 10 is obviously copied from the Supreme Court of Canada Rule 24, then still in force. Rule 18 does not come from the Supreme Court of Canada Rules, but seems to codify the intent and practice respecting factums.

1886 Rule 414 is the same.

The Judicature Ordinance, SNWT 1893, c 6, s 505.

Judicature Ordinance, 1898, supra note 55, r 505.

SNWT 1897, c 6, s 6.

Consolidated Rules of the Supreme Court of North-West Territories (Regina: 1900).

Ibid, r 9.

Ibid, r 10.

Ibid, r 11.

Ibid, rr 12, 14.

Ibid, r 16.

Ibid, r 18. 
The Northwest Territories Rules remained in force in Alberta until the Alberta judges passed new Rules of Court effective 1 September $1914 .{ }^{68}$

\section{E. Other Provinces: Manitoba AND ONTARio}

Given the history of the courts on the prairies, ${ }^{69}$ one might wonder whether Manitoba had an influence on this topic, but it appears not. The 1902 Manitoba Rules for appeals, under division VIII in The King's Bench Act, do not mention a factum by any name. ${ }^{70}$ The Manitoba Court of Appeal was created in 1906 and the King's Bench Act rules continued to apply. ${ }^{71}$ There was also no mention of factums in The Court of Appeal Act of 1913 and the Rules of Court following. ${ }^{72}$ No relevant change was contained in the 1924 statutes. ${ }^{73}$ Finally the Manitoba appellate judges enacted appellate rules. ${ }^{74}$ Rule 16 copied Ontario Rule 495 and called for a "statement of points relied on" (including citations of cases and evidence), which was expressly stated not to be a factum. ${ }^{75}$

Computer searching has not shown any Manitoba decision using the word "factum" in the appellate or procedural context before $1933 .^{76}$

Nor was Ontario any part of this process to introduce factums. Ontario did not allow factums until 1972. ${ }^{77}$ Indeed for many years before then the Ontario Rule expressly forbade a factum! ${ }^{78}$ As late as the 1960 s, the Registrar of the Supreme Court of Canada sometimes had trouble getting Ontario counsel to file factums with the Supreme Court of Canada. Even Ontario's bare heads of argument ${ }^{79}$ were often neglected. ${ }^{80}$ This confirms that Manitoba and Ontario were followers in written appellate argument. Quebec was the leader.

\section{Actual Alberta Practice}

The older closed files of the Alberta Court of Appeal are deposited in the Provincial Archives of Alberta. These files include the factums for each appeal and a considerable number of those boxes have been spot-checked for the period of 1908 through 1953. It would appear that on every appeal which proceeded, a factum was filed on each side (unless possibly one party had no lawyer).

Alberta Rules of Court, 1914, OIC, (1914) A Gaz II, 765.

See generally Louis A Knafla, ed, Law \& Justice in a New Land: Essays in Western Canadian Legal History (Toronto: Carswell, 1986).

RSM 1902, c 40, ss 647-87.

The Court of Appeal Act, SM 1906, c 18, ss 2(1), 14.

The Court of Appeal Act, RSM 1913, c 43.

An Act to Amend "The Court of Appeal Act", CSM 1924, c 43.

Rules of Court: Court of Appeal, printed in Manitoba, Acts of the Legislature of the Province of Manitoba 1934 (Winnipeg: 1934) at v-iii.

Ibid, $\mathrm{r} 16$.

The earliest case that mentions "factum" in the Quicklaw database is International Laboratories Ltd $v$ Dewar, [1933] MJ No 69 (QL) at para 52 (CA).

The Judicature Act, O Reg 115/72, s 501.

Ontario, The Rules of Practice and Procedure of the Supreme Court of Ontario (in Civil Matters), 1928 (Toronto: 1928), r 495; O Reg 396/60, r 501.

Permitted by the 1928 Rules (ibid) and required in Ontario after 1933: Donald Alexander MacRae, ed, Holmested and Langton on The Judicature Act of Ontario with Rules of Practice and Procedure of the Supreme Court of Ontario, 5th ed (Toronto: Carswell, 1940) at 1295.

80 See Kuczerky v Toronto Transportation Commission and Saracini, [1937] OR 256 at 261 (CA). 
Alberta factums have changed less over the years than one might expect. There was some tendency for the earlier ones to be short - sometimes quite short. ${ }^{81}$ Aside from length, it is difficult to detect any other major change over the years in the substance or content of the factums. In particular, it is difficult to say that the average quality of factums has changed significantly, though the older ones were somewhat less complex than those today. Of course from one case to another the quality of the factums varied quite a bit.

Before formal limits were placed on the length of a factum (a comparatively modern development), the average factum was significantly fewer than 30 pages. However, there have always been some fairly lengthy factums in cases which seemed complex and where a lot of money was involved.

It was not until 1974 that the Alberta Rules of Court provided that the contents of a factum were to be divided into four parts: facts, grounds of appeal, argument, and relief sought. ${ }^{82}$ Until then, most lawyers made up their own subdivisions or headings. Indeed, lawyers would sometimes give no subdivisions or headings in a shorter factum. For a great many years, it was common for factums to have just two divisions. The first was "facts" and the second was “argument.” Tables of cases or appendices of statutory material were rare.

From the earliest days, most factums had cardboard or heavy paper covers. However, there has been some change in physical appearance of factums. It was not until about 1966 that the Rules of Court required the appellant's factum to have a buff cover and the respondent's factum a green cover. ${ }^{83}$ Until then, it was rare for the covers' colours to show any conscious attempt to differentiate the two. In those days appeal books had grey covers; thus, the covers of the factums were not grey, but sometimes buff, blue, or brown. In the 1930s and 1940s, grey factum covers were fairly common, which must have made sorting out the papers confusing when the appeal books were not very thick. The first green cover for a respondent's factum, which I have found, was filed around 1935. Buff or yellow for an appellant's factum continued to be very rare.

Until computers became common, factums were always prepared on a typewriter. I did not find a single instance of a factum set in type and printed in a print shop. However, covers (but rarely contents) of appeal books were sometimes typeset and printed in a print shop. No factum cover was prepared that way (even though often it would have been easy, since much of the cover would be the same wording as the cover of the appeal books). Eschewing printed covers is curious, as preparing multiple copies of factum covers on a typewriter is a picky and repetitive job. I did not find any factum whose contents were mimeographed, multilithed, or offset, though the Rules permitted it and facilities for such a job were readily available.

In the 1960s, the court reporters in Edmonton prepared a certain number of the factums. But most of the factums which I saw looked as though they were prepared on a typewriter in the office of the law firm filing them. 
Except for the war years, the standard of typewritten factums seems to have been good. Virtually all were done on larger size of type (pica) found in office typewriters. A few were typed in the smaller size which was called elite. ${ }^{84}$ Occasionally, in the 1930s or 1940s one would see a typewriter with partly shaded type. These were probably manual typewriters. They produced a pleasant style of lettering a little more like the print from a book or a print shop and were precursors of the style of type later found on the IBM Selectric typewriter. ${ }^{85}$

Until photocopying of factums became common in the late 1960s, the pages of a factum were always typed using carbon paper. In order to make enough copies, the paper commonly used for the factum was thin onion skin paper. Sometimes the lawyers would interleaf blank sheets of standard paper between the flimsy pages to make them easier to read, but sometimes they did not. ${ }^{86}$ It was not until about halfway through the period surveyed that it became common for the lawyer filing a factum to endorse a pen-and-ink signature at the end of it.

I have only seen two factums which were bound at the top, as used to be common in other provinces or states with some types of legal documents such as wills. In all other factums, pages were attached at the left side of the cover so that the resulting pamphlet opened like a book. The pages were never typed on more than one side of the sheet of paper. Sometimes (as at present) they were bound in the right margin of the pages, so that only the left side of each pair of pages had writing on it. In the early days, that was not so common.

A very considerable variety of methods was used to attach the cardboard or heavy paper covers to the contents of the factum. Sometimes the fasteners were put through the outside of the factum and left showing, or they were covered in tape after that, and other times larger covers were used and folded so that the closed cover hid the fastener. The variety of fasteners used — different kinds of staples and brad nails — was remarkable. ${ }^{87}$

Until the early 1930s, court filing fees in Alberta were paid for by buying and affixing law stamps to the filed document. These were perforated, engraved, or lithographed, and looked rather like postage stamps, although larger. There was a considerable variety of denominations of law stamps, each with its own colour and rather attractive. ${ }^{88}$

There was some difficulty with theft and reuse of law stamps. ${ }^{89}$ In an attempt to be sure that law stamps were not fraudulently reused, stamps would be cancelled; unfortunately, the cancellations were often heavy. Most often they were cancelled by a rubber stamp, such as the filing stamp. However, for some years the Registrar in Calgary used to run a heavy smear of purple ink across the face of the stamp. It was effective, but it obliterated the stamp,

See e.g. Sarah Adams, Robert Rosemier \& Phillip Sleeman, "Readable Letter Size and Visibility for Overhead Projection Transparencies" (1965) 13:4 AV Communication Review 412 at 413.

85 See Darren Wershler-Henry, The Iron Whim: A Fragmented History of Typewriting (Toronto: McClelland \& Stewart, 2005) at 255.

86 That is how the University of Alberta Law Faculty then taught its students to prepare factums for moot court competitions.

87 It would intrigue even a collector of antiques, an archivist, or an expert in questioned documents.
${ }_{88}$ See ESJ van Dam, The Canadian Revenue Stamp Catalogue (Toronto: Unitrade Press, 2009) at 36 for illustrations of the different series of Alberta law stamps.

89 Presumably some stamps have been later removed from the files by collectors of stamps, as one sometimes sees places where stamps have been cut off the cover of a factum. 
making it difficult to look at its details. After the mid-1930s, cash register imprints were put on factums, and law stamps disappeared forever from Alberta. ${ }^{90}$

I did not see any handwritten notes or markings in the factums which I looked at in the Archives, so it is probable that the copy of the factums on each file was the file copy and the copies which were distributed to the judges have since been destroyed.

\section{CONCLUSION}

This topic is instructive because it shows that written advocacy took root quickly and flourished in the Northwest Territories and Alberta generations before it did elsewhere in common law Canada. It also illustrates the early influence of the Supreme Court of Canada and the successful grafting of civil law practice onto the common law tree. It also hints at how reluctant other provinces can be to follow good ideas from Quebec or the western provinces. 